\title{
Structural Change for Sustainable Development in Economy: A Literature Review
}

\author{
Viktorija Sipilova ${ }^{1, *}$ \\ ${ }^{1}$ Daugavpils University, the Institute of Humanities and Social Sciences, Centre of Social \\ Investigations, Parades street 1, Daugavpils, LV-5400, Latvia
}

\begin{abstract}
.
Research background: Climate change stimulates unfavorable global socio-economic consequences, which question economic structures, require sustainable development. Reaching sustainable development in economy relates to structural change. However, scientists rarely focus on structural change and sustainable development in the pure economic subject area.

Purpose of the article: The article aims to summarize and classify the knowledge about contribution and potential of structural change for sustainable development in economy using research experience. The author considers the articles published exactly in the economic subject area, in which scientists terminologically focus on structural change and sustainable development.

Methods: The search parameter - keywords and limitation - subject area determine the selection of suitable material for the research purpose. The author applies monographic method, logical analysis method, scientific induction method for the analysis of the selected material.

Findings \& Value added: The articles selected according to the limitations demonstrate that manufacturing is the most commonly analyzed sector followed by energy sector, tourism and decomposition of economy depending on sectoral efficiency. According to the material analyzed in the economic subject area, the contribution of structural change to sustainable development is considered in case studies with focus on decomposition of sectoral structure of local economies. Potential of structural change to sustainable development is considered in general terms and relates to energy efficiency, introduction of new technologies, and involvement of all stakeholders. Thus, it is possible to highlight the factors necessary for structural change, which work towards sustainable development in economy - attitude, efficiency, new technologies and wide range of participants.
\end{abstract}

Keywords: structural change; sustainable development; economy; literature review

JEL Classification: O10; O14; $Q 01$

* Corresponding author: sipilova.viktorija@inbox.lv 


\section{Introduction}

Scientists indicate that climate correlates with economic activity and particularly hotter areas and higher ultraviolet radiation are not favourable [1]. The recent global tendencies in climate change actualize imbalances between economic and environmental interests with negative socio-economic consequences for advanced and developing economies. Scientists try to understand effects on economy from pollution and search for desirable structural change [2]. Additionally, scientists highlight significance of globalization for industrial development and structural change [3]. Thus, sustainable development with seventeen aims become urgent challenge worldwide, especially in economic sphere.

Scientists consider possible solutions but each of them questions the existing economic structures and requires more or less pronounced structural change both between and within sectors. For example, possible solution relates to the cleaner production methods and practices [4]. Another solution relates to the pollution tax, which affects consumer demand [5]. One more solution offers society to slow down climate change by stimulating contributions of educational capital in some types of entrepreneurship [6]. Special role in the process of reorientation of entrepreneurship towards sustainability concept is devoted to business schools [7]. Finally, scientists highlight contribution of circular economy to sustainability [8].

Structural change means changes in relative importance of sectors of economy and may contribute to sustainable development in different sectors of economy. For example, scientists consider such sectors of economy as manufacturing [8], energy [9; 10], trade [10], tourism [11] and even primary sector [12] for testing direction, possible contribution and potential of structural change to sustainable development. Research findings indicate that structural change has to be accompanied by introduction of new technologies [13], involvement of all stakeholders [14;8], and by taking into account regional readiness for the process [8].

However, to the present, scientists also conclude about negative impacts on environment from structural change. Such negative effects may occur due to insufficient ability of firms to adjust for ongoing changes in sectoral structure and more sustainable practices [15], poor availability of data necessary for elaborating long-term models, for example, in energy supply and demand predictions [9]. Scientists also find that structural change in favour to knowledge economy sectors, which are recognized as desirable at the global level, does not necessarily mean higher sustainability rate. For example, scientists conclude that development of knowledge economy does not stimulate decrease in fossil fuel use [16].

The above-mentioned rises interest to focus on structural change and sustainable development exactly in the economic subject area. The present research is devoted to the analysis of articles, which consider structural change and sustainable development and are published in the economic subject area. This article is organized in four sections. The second section describes data and method. The third section presents the results of the analysis of some appropriate articles selected for the analysis according to the keywords and subject area. The fourth section contains discussion and conclusions. It is noteworthy that this research has two limitations - first, amount of articles in the mentioned thematic focus, second, limited length of article and allowed source count set in the requirements for the article formatting. However, despite limitations the present research arrange the knowledge about structural change and sustainable development in the economic subject area using the number of appropriate articles. 


\section{Data and method}

The purpose of the study is to summarize and classify the knowledge about structural change and sustainable development in economy using the articles selected according to the relevant keywords and subject area. The approach for the selection of the relevant articles is relatively narrow with the aim to select the most appropriate material and to receive overall picture about viewpoints published exactly in the economic subject area.

For the purpose, the author searches for the scientific articles devoted to the structural change and sustainable development according to the keywords. The search area is limited to Scopus database, however, the author checks, whether the selected items are covered by Web of Science Database as well. September 2020 is the search time. According to the keywords (search parameter "Keywords": "structural change" AND sustainable development) there are 93 articles in Scopus database. The present study focuses on articles in the economic subject area, therefore, the author limits search results by two subject areas - Economics, Econometrics and Finance; Business, Management and Accounting. Limitation excludes about $70 \%$ of the offered articles what demonstrates relative low interest in structural change and sustainable development in the pure economic context despite its high importance.

Thirteen articles in the subject area of Economics, Econometrics and Finance and thirteen articles in the subject area of Business, Management and Accounting remain for further manual check for suitability for the research purpose. After the manual check, nine articles remain, which relate to the selected context of the present study. The author excludes from the analysis those items, where exactly the parameter "Author keywords" does not include the selected keywords structural change, sustainable development. Several articles have structural change and sustainable development as "Indexed keywords" not "Author keywords", what is not suitable for the purpose of the present study. Exactly the parameter "Author keywords" is significant for the purpose of the present study, because the parameter "Author keywords" clearly defines intentions of researchers to devote attention to the concrete issues. Additionally, the author excludes some articles with inappropriate topical focus, and editorial note. Such approach allows concentrating attention on those articles, which are published in the economic subject area and where authors of the articles terminologically focus on structural change and sustainable development.

As a result, the author has nine articles for the analysis, which are published in eight journals. The subject areas of the journals are Economics, Econometrics and Finance; Business, Management and Accounting; Social Sciences; Environmental Science; Engineering; Energy. Web of Science Database covers seven of eight journals as well. The articles selected for the analysis were published from 1996 to 2020 October.

For the purpose of the article, the author considers appropriate scientific articles using monographic method, logical analysis method, and scientific induction method. The author takes into consideration, which accents are included in keywords, title and abstract - the items, which present the most important knowledge from the studies and which are the most commonly used for the selection of the relevant material by stakeholders.

\section{Results: Analysis of some appropriate articles}

The author organizes the research results in Table 1. The data on source and "Author keywords" provide the basis for the understanding of thematic focus in each article. The author searches for linked words in the titles of the selected articles, which discover highlights and intentions of researchers in their research aims. Thematic focus and sectoral focus allow for arranging the knowledge according to the sectoral occurrence of structural 
change and their meaning in the concrete cases. Finally, the author highlights structural change context for sustainable development within each article under consideration. Such organization of the analysis summarizes and classifies knowledge about structural change and sustainable development in the set of articles selected according to the relevant "Author keywords" and published in the economic subject area. As a result, it is clear, using the examples under analysis, the existing and potential contribution of structural change to sustainable development.

Table 1. Structural change and sustainable development in economy: results of the analysis.

\begin{tabular}{|c|c|c|}
\hline $\begin{array}{c}\text { Article } \\
\text { Author keywords }\end{array}$ & $\begin{array}{l}\text { Linked words in the title } \\
\text { Thematic focus } \\
\text { Sectoral focus }\end{array}$ & $\begin{array}{l}\text { Structural change context for } \\
\text { sustainable development within } \\
\text { the article }\end{array}$ \\
\hline $\begin{array}{c}{[8]} \\
\text { Authors' keywords: Biased } \\
\text { technological progress, Circular } \\
\text { economy, Economic growth, } \\
\text { Industrial structural change, } \\
\text { Industry } 4.0\end{array}$ & $\begin{array}{c}\text { In the title: Circular } \\
\text { economy, structural change } \\
\text { Thematic focus: Industry } \\
4.0 \text { and circular economy a } \\
\text { driving force for sustainable } \\
\text { development } \\
\text { Sectoral focus: } \\
\text { Manufacturing, Industry }\end{array}$ & $\begin{array}{l}\text { Industrial structural change } \\
\text { driving by technological progress } \\
\text { focusing on energy and } \\
\text { environment issues. } \\
\text { Regional readiness and } \\
\text { involvement of all stakeholders } \\
\text { as policymakers' task. }\end{array}$ \\
\hline $\begin{array}{c}{[11]} \\
\text { Authors' keywords: } \\
\text { Employment, Poverty, pro-poor } \\
\text { tourism, SDG, structural change, } \\
\text { well-being }\end{array}$ & $\begin{array}{l}\text { In the title: SDG1 } \\
\text { Thematic focus: Poverty } \\
\text { end as SDG 1, well-being } \\
\text { Sectoral focus: Tourism } \\
\text { (service sector) }\end{array}$ & $\begin{array}{l}\text { Structural inequalities, which } \\
\text { hinder poverty end. The tourism } \\
\text { sector is used as the example. }\end{array}$ \\
\hline $\begin{array}{c}{[10]} \\
\text { Authors' keywords: De- } \\
\text { materialisation, Pollution haven } \\
\text { hypothesis, Structural change, } \\
\text { Sustainable development, } \\
\text { Tertiarisation }\end{array}$ & $\begin{array}{l}\text { In the title: Structural } \\
\text { Changes and sustainability } \\
\text { Thematic focus: Review on } \\
\text { empirical evidence about } \\
\text { structural change and } \\
\text { sustainability } \\
\text { Sectoral focus: Sectoral } \\
\text { composition of economy } \\
\text { and its changes, } \\
\text { tertiarisation }\end{array}$ & $\begin{array}{l}\text { Structural changes that affect } \\
\text { emissions and energy intensity: } \\
\text { energy, trade, sectoral } \\
\text { composition of economies, } \\
\text { technologies, innovation }\end{array}$ \\
\hline $\begin{array}{c}{[13]} \\
\text { Authors' keywords: Development } \\
\text { economics, New Structural } \\
\text { Economics, Poverty elimination, } \\
\text { Structural changes, Sustainable } \\
\text { development goals }\end{array}$ & $\begin{array}{l}\text { In the title: Structural } \\
\text { change } \\
\text { Thematic focus: Poverty } \\
\text { end as SDG1, New } \\
\text { Structural Economics } \\
\text { Sectoral focus: - }\end{array}$ & $\begin{array}{c}\text { Structural change accompanied } \\
\text { by introduction of new } \\
\text { technologies and creation of new } \\
\text { jobs for income increase }\end{array}$ \\
\hline $\begin{array}{c}{[15]} \\
\text { Authors' keywords: Industrial } \\
\text { transition, Industry dynamics, } \\
\text { Structural changes, Sustainable } \\
\text { development }\end{array}$ & $\begin{array}{l}\text { In the title: Industrial } \\
\text { transition, sustainable } \\
\text { development } \\
\text { Thematic focus: Industrial } \\
\text { transition } \\
\text { Sectoral focus: } \\
\text { Manufacturing } \\
\end{array}$ & $\begin{array}{l}\text { Ability of firms to adjust to } \\
\text { industrial transition and } \\
\text { structural changes for more } \\
\text { sustainable practices and } \\
\text { industrial competitiveness }\end{array}$ \\
\hline $\begin{array}{c}{[17]} \\
\text { Authors' keywords: } \\
\text { Decomposition analysis, Input- } \\
\text { output model, Malaysia, } \\
\text { Structural change, Sustainable } \\
\text { development }\end{array}$ & $\begin{array}{l}\text { In the title: Structural } \\
\text { changes } \\
\text { Thematic focus: Structural } \\
\text { change in intermediate } \\
\text { demand and total output in } \\
\text { Malaysia in long term } \\
\text { Sectoral focus: Economic } \\
\text { structure decomposed in }\end{array}$ & $\begin{array}{l}\text { Structural change as the result of } \\
\text { changes in the level of efficiency } \\
\text { within sectors of economy. } \\
\text { Efficiency is significant for } \\
\text { sustainability. }\end{array}$ \\
\hline
\end{tabular}




\begin{tabular}{|c|c|c|}
\hline & $\begin{array}{l}\text { technology, intermediate } \\
\text { and total output }\end{array}$ & \\
\hline $\begin{array}{c}{[12]} \\
\text { Authors' keywords: Endogenous } \\
\text { growth, Natural resources, } \\
\text { Structural change, Sustainable } \\
\text { development }\end{array}$ & $\begin{array}{l}\text { In the title: Structural } \\
\text { change and sustainable } \\
\text { development } \\
\text { Thematic focus: Natural } \\
\text { resources, economic growth } \\
\text { and sustainable } \\
\text { development relationship } \\
\text { Sectoral focus: Primary } \\
\text { sector }\end{array}$ & $\begin{array}{l}\text { Structural change may allow } \\
\text { growth in an open economy with } \\
\text { natural resources sustainability }\end{array}$ \\
\hline $\begin{array}{c}{[9]} \\
\text { Authors' keywords: Energy- } \\
\text { related models, Industrial } \\
\text { development, Structural change } \\
\text { policies }\end{array}$ & $\begin{array}{l}\text { In the title: Industrial } \\
\text { development } \\
\text { Thematic focus: Planning of } \\
\text { energy supply and demand } \\
\text { in long term } \\
\text { Sectoral focus: Energy } \\
\text { sector, industry }\end{array}$ & $\begin{array}{l}\text { Initiated structural changes for } \\
\text { decreasing inefficient energy use } \\
\text { at the sectoral level and } \\
\text { introducing sustainable and cost- } \\
\text { efficient energy resources }\end{array}$ \\
\hline $\begin{array}{c}{[14]} \\
\text { Authors' keywords: Alternative } \\
\text { strategy, Benefit-cost analysis, } \\
\text { Methodology, Structural change, } \\
\text { Sustainable policies }\end{array}$ & $\begin{array}{l}\text { In the title: Changes, } \\
\text { ecological economics } \\
\text { Thematic focus: } \\
\text { Methodological issues of } \\
\text { correct assessment of } \\
\text { gigantic projects on society, } \\
\text { ecology, transport and } \\
\text { production systems } \\
\text { Sectoral focus: Transport } \\
\text { and production systems }\end{array}$ & $\begin{array}{l}\text { Participation of all stakeholders } \\
\text { in structural changes as a result } \\
\text { of gigantic project. Correct } \\
\text { evaluation of the results. }\end{array}$ \\
\hline
\end{tabular}

Source: elaborated by the author using $[8 ; 9 ; 10 ; 11 ; 12 ; 13 ; 14 ; 15 ; 17]$.

In the articles under the analysis, scientists link economic well-being with environmental preservation and in most cases highlight the role of technologies for better adjustments of sectoral composition of economy to urgent environmental issues. Analysis of the keywords used within the considered articles indicates that scientists understand necessity of structural change initiation and evaluation in terms of poverty, industrial development, circular economy, and sources for economic growth. The attention is paid exactly to the articles, which indicate structural change and sustainable development process in the "Author keywords".

Publishing time of the selected articles about structural change and sustainable development in the economic subject area discovers pauses in research activities. Time line of the selected articles covers about 24 years, but articles were published with significant gaps. One article was published in 1996, two articles in 2007, one in 2015, one in 2018, three in 2019, and one in 2020. Thus, it is possible to conclude that structural change and sustainable development in the economic subject area all are the more relevant research themes only during past few years.

Sectoral focus, within the selected articles, relates to the main sectors of economy primary, secondary, tertiary, and quaternary sectors. It is noteworthy that authors almost equally pay attention to structural change within sectors and between them. Manufacturing is the most commonly analysed sector for the evaluation of possibilities how to balance economic and environmental interests at the more detailed sectoral level. Besides manufacturing sector, scientists consider energy sector, tourism sector. Additionally, scientists try to make analysis using sectoral decomposition depending on sectoral efficiency what is one of the most significant factors for sustainable development. 
The contribution of structural change to sustainable development mostly is presented by using the cases of local economies. Potential of structural change to sustainable development is more generalized and includes several positions. First, scientists indicate that involvement of all stakeholders is crucial for the new path of industrial development, reducing structural inequalities, correct understanding of long-term effects on society and environment. Second, scientists highlight necessity to develop production systems with low emissions and put more attention on energy sector. Third, scientists indicate that new technologies are driving force for reaching the above-mentioned aims.

It is noteworthy that authors include the terms - structural change and sustainable development - in the titles of their articles. As one can see from the Table 1 scientists include the keyword "structural change" in the titles. Similar situation with the keyword "sustainable development" is. However, in this case, authors more diversify the term use. Such tendency indicates that scientists devote serious attention to the research theme, and consider terms "structural change" and "sustainable development" as suitable, correct for indicating the sense of their studies.

\section{Discussion and conclusions}

Sustainable development comprises seventeen aims, which reflect needs in every sphere of human life. Inspired by the sustainability concept scientists indicate the necessity to solve sustainability issues from the transdisciplinary perspective, focusing not only on natural sciences but also on social sciences [18]. In this perspective, the economic subject area is of high importance, because exactly the existing and possible mismatches between environmental and economic interests impede fostering of sustainable development. Structural change is a possible tool in searching the balance between polar interests.

In general, structural change and sustainable development in the economic subject area are considered seldom comparing with other subject areas. There are gaps in publishing time. Sometimes one can see different accents, sometimes the common viewpoints in context of the role of structural change for sustainable development.

Despite of the pronounced tertiarization of the economy worldwide, scientists continue to consider structural change within and between all main sectors of economy - primary, secondary, tertiary, and quaternary. In context of sustainability, this is necessary due to high importance of technologies for rising the cleaner production, replacement of fossil fuel, rising efficiency and preserving natural resources in every sector of economy. Additionally, there are the pronounced differences in sectoral structure of economy between developing and advanced countries what set the aim to focus on every sector in the processes of poverty end.

Mostly scientists focus on manufacturing, industry and energy sector by indicating necessity in more sustainable practices and introduction of new technologies, increasing efficiency. Primary and tertiary sectors are considered also, but in lesser degree. Technologies are considered as catalyst for sustainable oriented structural change. Institutional environment and involvement of all stakeholders are mentioned as necessary preconditions for sustainability. The analysis of the selected articles allows for highlighting the main factors necessary for structural change, which work towards sustainable development. These factors are attitude, efficiency, new technologies and wide range of participants.

The contribution of structural change to sustainable development mostly is considered in case studies what does not allow for generalization of the results. These case studies focus on decomposition of sectoral structure of local economies. In turn, potential of structural change to sustainable development is considered in general terms and relates to 
energy efficiency, introduction of new technologies, involvement of all stakeholders, following to the principles of circular economy, introducing Industry 4.0.

It is noteworthy that sustainability concept in economic activities is relatively widespread across scientific studies. However, it is not so widespread in articles published exactly in the economic subject area. Thus, limitations of the present research relates to the search parameters - keywords, subject area. Widening of publishing subject areas and focusing on thematic directions within articles could help to increase amount of the relevant articles. Although, the considered articles discover significant insight in the thematic and sectoral focuses and the role of structural change to sustainable development.

\section{References}

1. Andersen, T. B., Dalgaard, C. J., \& Selaya, P. (2016). Climate and the emergence of global income differences. The Review of Economic Studies, 83(4), 1334-1363.

2. Germain, M. (2020). Limits to growth and structural change. Structural Change and Economic Dynamics, 55, 204-221.

3. Romano, L., Traù, F. (2017). The nature of industrial development and the speed of structural change. Structural Change and Economic Dynamics, 42, 26-37.

4. Giannetti, B.F., Agostinho, F., Cabello Eras, J.J., Zhifeng Yang, Almeida, C.M.V.B. (2020). Cleaner production for achieving the sustainable development goals. Journal of Cleaner Production, 271, 122127.

5. Lopez, R.E., Yoon, S.W. (2020). Sustainable development: Structural transformation and the consumer demand. Structural Change and Economic Dynamics, 52, 22-38.

6. Omri, A., Afi, H. (2020). How can entrepreneurship and educational capital lead to environmental sustainability? Structural Change and Economic Dynamics, 54, 1-10.

7. Gast, J., Gundolf, K., Cesinger, B. (2017). Doing business in a green way: A systematic review of the ecological sustainability entrepreneurship literature and future research directions. Journal of Cleaner Production, 147, 44-56.

8. Zhou, X., Song, M., \& Cui, L. (2020). Driving force for China's economic development under Industry 4.0 and circular economy: Technological innovation or structural change?. Journal of Cleaner Production, 271, 122680.

9. Miranda-da-Cruz, S.M. (2007). A model approach for analysing trends in energy supply and demand at country level: Case study of industrial development in China. Energy Economics, 29(4), 913-933.

10. Savona, M., Ciarli, T. (2019). Structural Changes and Sustainability. A Selected Review of the Empirical Evidence. Ecological Economics, 159, 244-260.

11. Scheyvens, R., Hughes, E. (2019) Can tourism help to "end poverty in all its forms everywhere"? The challenge of tourism addressing SDG1. Journal of Sustainable Tourism, 27(7), 1061-1079.

12. Lopez, R.E., Anríquez, G., Gulati, S. (2007). Structural change and sustainable development. Journal of Environmental Economics and Management, 53(3), 307-322.

13. Lin, J.Y. (2019). Structural change and poverty elimination. China Agricultural Economic Review, 11(3), 452-459.

14. Barkin, D., Bucher, E.H., Huszar, P.C. (1996). Macro changes and micro analysis: Methodological issues in ecological economics. Ecological Economics, 19(3), 197200. 
15. Tsai, D.H.A. (2018). The effects of dynamic industrial transition on sustainable development. Structural Change and Economic Dynamics, 44, 46-54.

16. Rezny, L., Buchanan White, J., Maresova, P. (2019). The knowledge economy: Key to sustainable development? Structural Change and Economic Dynamics, 51, 291-300.

17. Bekhet, H.A., Yasmin, T. (2015). Modelling the structural changes sources of the Malaysian economy: I-O model. International Journal of Economics and Business Research, 10(2), 125-147.

18. Shrivastava, P., Smith, M. S., O’Brien, K., \& Zsolnai, L. (2020). Transforming Sustainability Science to Generate Positive Social and Environmental Change Globally. One Earth, 2(4), 329-340.. 